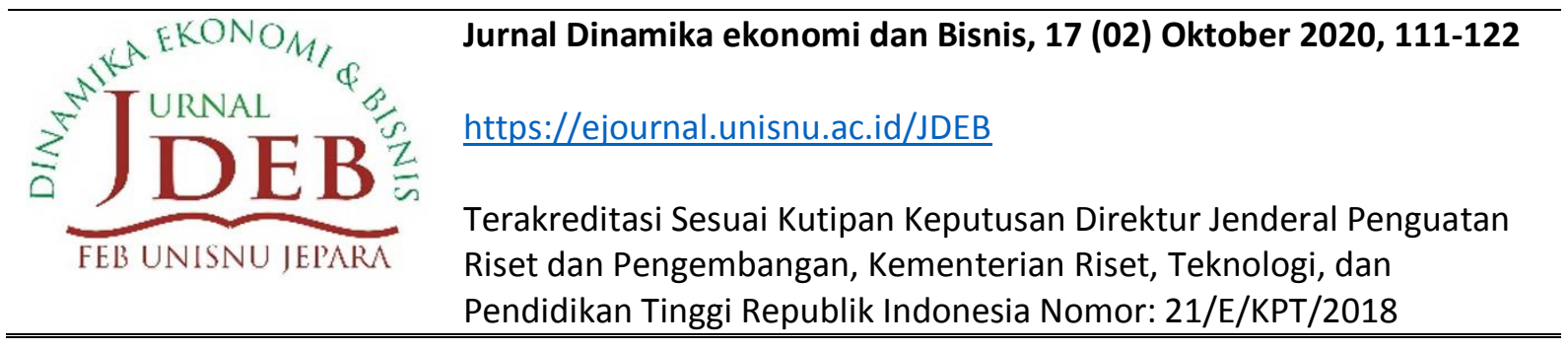

\title{
PENENTU HARGA SAHAM PADA PERUSAHAAN TERDAFTAR DI JAKARTA ISLAMIC INDEX (JII)
}

\author{
Ratna Ayu Widyastuti ${ }^{1)}$, Edi Susilo ${ }^{2) *}$ \\ Fakultas Ekonomi dan Bisnis, Universitas Islam Nahdlatul Ulama Jepara ${ }^{1,2)}$ \\ edisusilo@unisnu.ac.id ${ }^{2)}$
}

\begin{abstract}
This study aims to analyze the effect of Return on Equity (ROE), Earning per Share (EPS), Inflation, and Exchange Rates on stock prices listed on the Jakarta Islamic Index (JII) for the 2015-2018 period. This research is a quantitative research based on secondary data from the Indonesia Stock Exchange. There are 45 stock listed in the JII index, which can be used as population. Purposive sampling as a sampling technique. Based on the criteria, 17 companies were sampled. Data analysis used multiple linear regression using SPSS version 20 program. The results showed that, partially, Return on Equity (ROE) has a positive and significant effect, followed by the Earning per Share (EPS). The variables that do not partially affect stock prices are inflation and exchange rates. Meanwhile, Return on Equity (ROE), Earning per Share (EPS), inflation, and exchange rate simultaneously affect the share price of JII for the 2015-2018 period..
\end{abstract}

Keywords: EPS, Stock Price, Inflation, Exchange Rate, ROE

\section{Abstrak}

Tujuan penelitian ini, untuk mengamati pengaruh Return on Equity (ROE), Earning per Share (EPS), Inflasi, dan Kurs terhadap harga saham Jakarta Islamic Index periode 2015-2018. Penelitian termasuk penelitian kuantitatif berbasis data sekunder dari Bursa Efek Indonesia. Terdapat 45 saham terdaftar di indeks JII, yang dapat dijadikan sebagai populasi. Purposive sampling sebagai teknik sampling. Berdasarkan kriteria, terdapat 17 perusahaan yang dijadikan sampel. Analisis data menggunakan regresi linear berganda menggunakan program SPSS versi 20. Hasil penelitian menunjukkan bahwa, secara parsial variabel Return on Equity (ROE) memiliki pengaruh yang positif dan signifikan, demikian juga variabel Earning per Share (EPS. Variabel yang tidak memiliki pengaruh pada harga saham secara parsial adalah inflasi dan kurs. Sedangkan Return on Equity (ROE), Earning per Share (EPS), inflasi, dan kurs, secara simultan mempengaruhi harga saham JII periode 2015-2018.

Kata Kunci : EPS, Harga Saham, Inflasi, Kurs, ROE

Sitasi: Widyastuti, R. A. \& Susilo, E. Penentu Harga Saham pada Perusahaan Terdaftar di Jakarta Islamic Index (JII). Jurnal Dinamika Ekonomi dan Bisnis, 17 (02) 2020, 111-122. 


\section{PENDAHULUAN}

Peran strategis pasar modal di era globalisasi saat ini sangat penting sebagai faktor ketahanan ekonomi Negara, karena system perekonomian menjadi semakin terbuka, dan investor dapat melakukan investasi di semua Negara, sesuai keinginannnya. Pasar modal menalami perubahan yang begitu cepat, sehingga memberi dampak besar bagi keputusan investor untuk berinvestasi (Touny, 2012). Investor selalu melihat dua faktor yaitu risk and return (hasil dan risiko), maka harga saham menjadi dasar utama investasi, karena harga saham mencerminkan nilai perusahaan, semakin meningkatnya harga saham mencerminkan nilai perusahaan di mata publik (Nicolae, Codruta, Violeta, \& Adriana, 2016). Pasar modal berperan penting sebagai instrument keuangan, terutama instrument jangka panjang pada Pasar modal (capital market), dimana diperjual-belikan surat utang maupun ekuitas (Darmadji \& Fakhruddin, 2012). Undang-undang No.8 tahun 1995 menyatakan pasar modal merupakan kegiatan perdagangan efek perusahaan kepada publik.

Pasar modal syariah diartikan sebagai pasar modal dimana mekanisme perdagangannya berdasarkan prinsip-prinsip syariah, dan terlepas dari riba, gharar (ketidakjelasan), dan perjudian. Saat ini telah diperdagangkan saham syariah sebagai instrument pasar modal di Indonesia. Saham syariah diperdagangkan melalui Bursa Efek Indonesia (BEI), setelah dibentuk Jakarta Islamic Index pada 3 Juli 2000. Saham yang diperdagangkan adalah saham Bursa Efek Indonesia, yang telah lolos screening dan memenuhi kriteria syariah (Rachmawati \& Laila, 2015). Tercatat 45 saham dengan kriteria syariah diperdagangkan di JII, sehingga JII saat ini telah menjadi pilihan alternatif dalam berinvestasi, terutama pilihan investasi halal di Bursa yang menerapkan prinsip syariah. Pergerakan saham JII dalam beberapa tahun ini bergerak fluktuatif, pada tahun 2013, indeks saham JII mencapai 585,11, meningkat menjadi 691,04 di 2014. Tahun 2015 saham JII mengalami penurunan 603,35 kemudian naik sampai dengan 2017 dengan jumlah saham sebesar 759,07 akan tetapi mengalami penurunan 685,22 pada tahun 2018.

Dalam membuat keputusan, seorang investor mempertimbangkan berbagai faktor yang diperkirakan dapat menguntungkan, dengan cara menganalisis terhadap saham dan kondisi keuangan perusahaan tempat menanamkan modal. Analisis ini untuk menghindari kerugian. Analisis harga saham dapat dilakukan: Pertama secara fundamental; yang didasarkan pada rasio keuangan perusahaan, diperoleh dari perhitungan rasio atas laporan keuangan perusahaan. Analisis rasio memperlihatkan kinerja perusahaan. Kedua secara teknikal; dengan cara memperhatikan trend naik dan turunanya harga saham di Bursa Saham (Kousar, Imran, Khan, \& Khurram, 2019). Kecermatan dalam menganalisis perkembangan indeks harga saham sangat menentukan ketepatan dalam berinvestasi, karena analisis teknikal mengabaikan kinerja perusahaan dalam jangka pendek. Menurut Ardana (2016) terdapat faktor-faktor seperti inflasi, BI-rate, jumlah uang yang beredar, nilai tukar (kurs), pertumbuhan ekonomi, dapat mempengaruhi harga saham. Sedangkan variabel internal yang mampu mempengaruhi harga saham dapat dilihat dari rasio keuangan perusahaan tersebut seperti ROA, ROE, PBV, DER, EPS dan lain-lain. 
Return on Equity (ROE) mencerminkan tingkat laba dari modal yang dimiliki oleh milik perusahaan. Semakin besar nilai rasio, semakin besar laba yang didapatkan. Penelitian Riana \& Dewi (2015) dan Wijayanti \& Sulasmiyati (2018), menyebutkan bahwa ROE mempengaruhi harga saham secara signifikan. Sedangkan penelitian Akbar \& Afiezan (2018) dan Utami \& Darmawan (2019), menunjukkan bahwa faktor internal ROE tidak mempengaruhi harga saham secara signifikan. EPS atau Earning per Share merupakan perbandingan besarnya laba per lembar dari investasi pembilian saham oleh investor yang diterima setiap periode. EPS memberikan informasi yang dapat memproyeksikan pendapatan perusahaan, oleh karena itu besar kecilnya EPS mengindikasikan besaran pendapatan investor di masa depan dan menjadi faktor penting dalam berinvestasi (Tandelilin, 2010). EPS yang tinggi menjadi parameter suksesnya sebuah perusahaan, sehingga secara langsung mempengaruhi naiknya harga saham. Penelitian Desiana (2017) dan Syarief (2019) berkesimpulan bahwa salah satu yang merpengaruhi harga saham adalah EPS.

Inflasi mencerminkan harga saat ini dibanding dengan harga periode sebelumnya dari dan terjadi secara terus menerus, penurunan harga disebut dengan deflasi. Kenaikan harga yang dimaksud adalah kenaikan harga secara aggregate (kumpulan dari semua barang dan jasa) dari periode sebelumnya (Boediono, 1999). Penelitian Sari (2016) menunjukkan bahwa faktor eksternal inflasi ternyata berpengaruh positif pada harga saham. Sedangkan Akbar \& Afiezan (2018) menunjukkan hal yang sebaliknya pada harga saham. Sementara Rachmawati \& Laila (2015) serta Rahmania, Mardani \& Wahono (2019) menunjukkan fakta berlawan, yaitu negatif signifikan.

Kurs (nilai tukar) adalah perbandingan nilai mata Negara satu dengan Negara lainnya. Ketika suatu negara melakukan pertukaran barang atau jasa dengan negara lain, maka saat itu telah terjadi pertukaran mata uang (Bank Indonesia, 2019). Hasil penelitian Rachmawati \& Laila (2015) menunjukkan bahwa terdapat nilai tukar (kurs), mempengaruhi harga saham, sementara penelitian Harahap (2016) yang menunjukkan hal sebaliknya. Penelitian terdahulu menunjukkan bahwa, banyak faktor penting berkaitan dengan perubahan harga saham. Kesamaan variabel penelitian ternyata menghasilkan kesimpulan yang berbeda, hal ini menunjukkan terjadinya ketidakkonsistenan hasil dari beberapa penelitian terdahulu.

Faktor internal merupakan faktor kinerja perusahaan secara internal dalam suatu periode. Salah satu ukuran kinerjanya adalah rasio keuangan perusahaan dan kinerja keuangan yang dilaporkan setiap periode, baik setiap bulan, triwulan, semester, mapun tahunannya. Selain factor internal, harga saham juga dipengaruhi faktor diluar perusahaan seperti nilai tukar, inflasi, suku bunga dan kondisi makro lainnya (Tandelilin, 2010). Faktor internal penlitian memilih profitabilitas yang tercermin dari ROE dan EPS, sedangkan factor eksternal inflasi dan kurs dipilih sebagai variabel yang mempengaruhi harga saham di JII.

Return on Equity (ROE) mencerminkan laba yang dihasilkan dari modal yang dimiliki perusahaan. Dengan membandingkan laba bersih yang diperoleh dalam periode tertentu, dengan jumlah modal sendiri, sebagai cermin dari efisiensi penggunaan modal untuk operasional perusahaan (Tandelilin, 2010). Modal yang besar adalah satu nilai lebih 
perusahaan, namun belum tentu modal yang besar mencerminkan kinerja yang besar pula. Maka efisiensi penggunaan modal ini tercermin dari ROE.

Earning per Share (EPS) menggambarkan besarnya laba dari saham per lembarnya yang akan diterima investor. EPS saat ini dapat menjadi prediksi return masa depan (Tandelilin, 2010). Tingggi rendahnya EPS mencerminkan prospek perusahaan, bila EPS tinggi, berprospek tinggi, begitupun EPS yang rendah, maka prospek perusahaan tersebut kurang baik (Samsul, 2006).

Inflasi adalah kecenderungan kenaikan harga secara kontinu secara aggregate (harga keseluruhan barang dan jasa) (Boediono, 1999). Harga barang yang terus mengalami kenaikan, bila tidak diimbangi dengan tingkat peredaran uang, maka akan mengalami inflasi, sehingga nilai uang turun (devaluasi), dan harga di tingkat konsumsi masyarakat mengalami kenaikan diukur indeks harga saat ini dibanding dengan periode sebelumnya, diukur dari indeks harga konsumen (consumer price index) (Bank Indonesia, 2019).

Kurs (nilai tukar) adalah nilai mata uang antar Negara ketika terjadi pertukaran mata uang. Terdapat tiga model penentuan nilai tukar yang dikemukakan The Fei Ming dalam (Fahmi, 2014) yaitu : Traditional Theories, Modern Theories dan Synthesis of Traditional and Modern Monetary Views. Teori ini menjelaskan bahwa dinamika di pasar keuangan (pasar modal dan pasar uang) selalu mengalami perubahan. Menurut Samsul (2006), variabel makro ekonomi tidak sama dampaknya terhadap harga saham, bisa berdampak positif, di satu saham namun bisa berdampak negatif pada harga saham lainnya.

\section{METODE}

\section{Kerangka Pemikiran Teori}

Kerangka pemikiran teoritis penelitian ini dapat dilihat pada gambar dibawah ini :

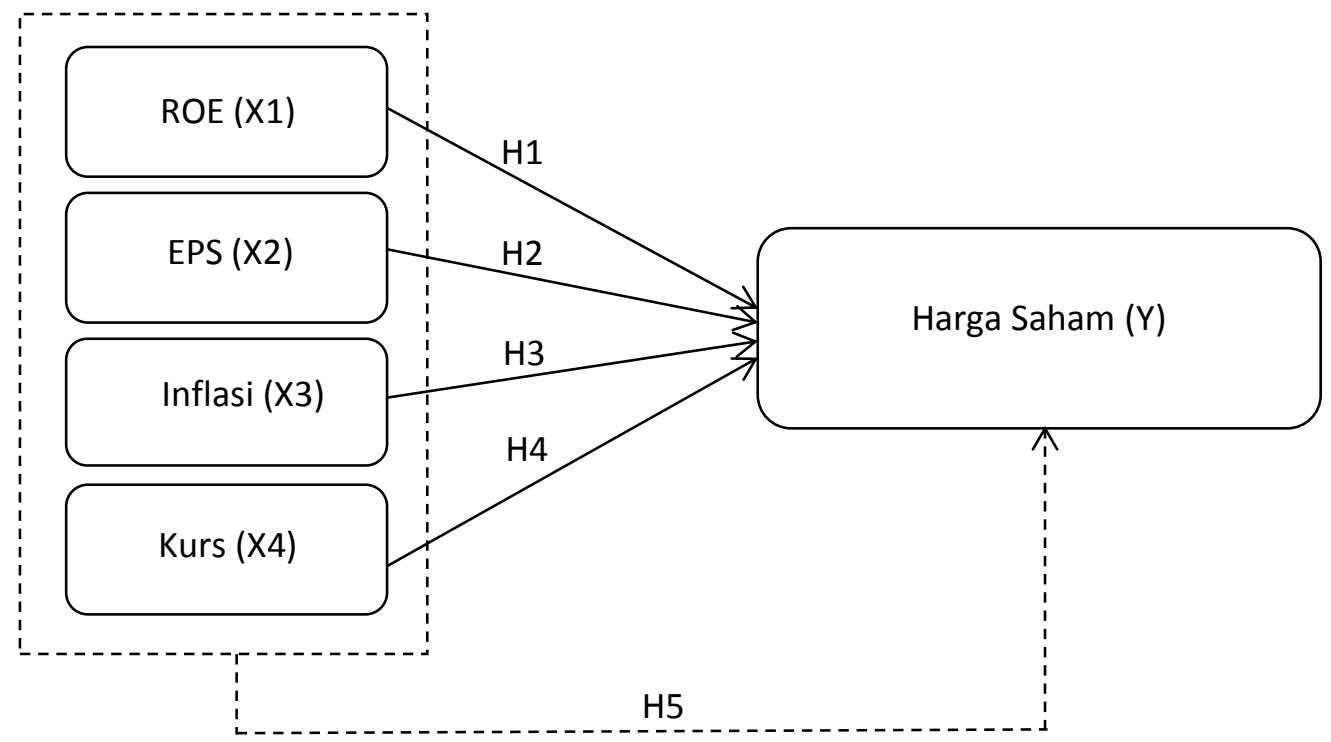

Gambar 1 Kerangka Pemikiran Teoritis 


\section{Keterangan:}
$\longrightarrow=$ Uji statistik partial (uji $\mathrm{t}$ atau pengujian secara individu), yaitu pengujian koefisien regresi secara parsial dengan menentukan formula statistik yang akan diuji.
- - - = Uji Secara Simultan (uji F) pengujian ini dilakukan untuk mengetahui secara serentak atau bersama-sama variabel independen berpengaruh secara signifikan atau tidak terhadap variabel dependen.

Penelitian ini menggunakan hipotesis sesuai kerangka pemikiran teoritis di atas, sebagai berikut: H1: Diduga Return on Equity (ROE) memiliki pengaruh positif secara signifikan terhadap harga saham. H2: Diduga Earning per Share (EPS) berpengaruh positif dan signifikan terhadap harga saham. H3: Diduga inflasi berpengaruh signifikan negatif pada harga saham. H4: Diduga Kurs berpengaruh signifikan negatif terhadap harga saham. H5: Diduga ROE, EPS, inflasi dan kurs mempengaruhi harga saham secara silmultan.

Penelitian kuantitatif menjadi pilihan dalam penelitian ini, dengan menggunakan data sekunder dengan time series, dimana data diperoleh melalui media perantara berbentuk angka secara tidak langsung, kemudian data diolah dan dianalisa meggunakan teknik perhitungan statistik.

Populasi adalah perusahaan tercatat di JII, periode tahun 2015 sampai dengan tahun 2018, dengan jumlah populasi sebanyak 45 perusahaan. Sampling dilakukan secara purposive sampling, sesuai kriteria yang ditetapkan (Sugiyono, 2014). Kriteria yang digunakan adalah: Perusahaan yang sahamnya terdaftar dan konsisten masuk sebagai anggota indeks JII di Bursa Efek Indonesia selama periode 2015-2018, yang secara rutin terpublikasi laporan keuangannya selama periode penelitian.

Berdasarkan kriteria tersebut, dari 45 saham JII selama periode 2015-2018 yang menjadi populasi dalam penelitian ini. Sampel ditetapkan 17 saham yang konsisten selama periode penelitian. Perusahaan yang menjadi sampel penelitian ini dapat dilihat secara lebih jelas dalam tabel berikut : 
Tabel 1. Sampel Penelitian.

\begin{tabular}{ccl}
\hline No & Kode & \multicolumn{1}{c}{ Nama Perusahaan } \\
\hline 1 & ADRO & Adaro Energy Tbk. \\
2 & AKRA & AKR Corporindo Tbk. \\
3 & ASII & Astra International Tbk. \\
4 & BSDE & Bumi Serpong Damai Tbk. \\
5 & ICBP & Indofood CBP Sukses Makmur Tbk. \\
6 & INCO & Vale Indonesia Tbk. \\
7 & INDF & Indofood Sukses Makmur Tbk. \\
8 & KLBF & Kalbe Farma Tbk. \\
9 & LPKR & Lippo Karawaci Tbk. \\
10 & PGAS & Perusahaan Gas Negara Tbk. \\
11 & PTPP & PP (Persero) Tbk. \\
12 & SMGR & Semen Indonesia (Persero) Tbk. \\
13 & SMRA & Summarecon Agung Tbk. \\
14 & TLKM & Telekomunikasi Indonesia (Persero) Tbk. \\
15 & UNTR & United Tractors Tbk. \\
16 & UNVR & Unilever Indonesia Tbk. \\
17 & WIKA & Wijaya Karya (Persero) Tbk. \\
\hline Sumber : Bursa Efek Indonesia (2019)
\end{tabular}

Pengolahan data pada penelitian ini menggunakan bantuan sofware SPSS Statistics 20.0 (Stastical Product and Service Solucions). Beberapa aspek yang dapat dilakukan pada penelitian ini meliputi: Analisis Statistik Deskriptif, Uji Asumsi Klasik, Uji Normalitas, Uji Multikolinearitas, Uji Heteroskedastisitas, Uji Autokorelasi, Analisis Regresi Berganda, Uji t dan Uji F.

Analisis regresi berganda dilakukan untuk mengetahui seberapa besar pengaruh antara variabel $\operatorname{ROE}\left(\mathrm{X}_{1}\right)$, EPS $\left(\mathrm{X}_{2}\right)$, inflasi $\left(\mathrm{X}_{3}\right)$, kurs $\left(\mathrm{X}_{4}\right)$ terhadap harga saham $(\mathrm{Y})$. Model tersebut dapat dinyatakan:

Keterangan:

$$
\mathbf{Y}=\alpha+\beta_{1} \mathbf{X}_{1}+\beta_{2} \mathbf{X}_{2}+\beta_{3} \mathbf{X}_{3}+\beta_{4} \mathbf{X}_{4}+\mathbf{e}
$$

Y : Harga Saham

$\alpha \quad$ : Konstanta

$\mathrm{X}_{1} \quad: \mathrm{ROE}$

$\mathrm{X}_{2} \quad$ : EPS

$\mathrm{X}_{3} \quad$ : Inflasi

$\mathrm{X}_{4} \quad:$ Kurs

e $\quad$ : Standart error estimation

$\beta_{1}, \beta_{2}, \beta_{3}, \beta_{4}$ : Koefisien independen variable yang diregress 


\section{HASIL}

\section{Uji Asumsi Klasik}

Hasil uji normalitas nilai signifikansi sebesar 0,197 > 0,05, dengan demikian, nilai residual berdistribusi secara normal. Variabel ROE dan variabel EPS mempunyai nilai tolerance yang sama yaitu sebesar 0,852 dan nilai VIF masing-masing sebesar 1,174. Variabel inflasi memiliki nilai tolerance sebesar 0,857 dan nilai VIF sebesar 1,167 sedangkan variabel kurs memiliki nilai tolerance sebesar 0,856 dan nilai VIF sebesar 1,169. Maka seluruh variabel memiliki tolerance diatas 0,1 dan memiliki nilai Variance Inflation Factor dibawah 10 dan tidak terjadi gejala multikolinieritas dalam panel penelitian ini. Hasil uji heteroskedastisitas menunjukkan titik tersebar pada bagian atas angka nol dan dibawah angka nol, artinya terbebas dari heteroskedastisits. Nilai Durbin Watson hitung sebesar 1,880 dengan signifikansi 0,05 dengan $\mathrm{n}=68$ dan jumlah variabel independen $(\mathrm{k}=4)$ sehingga didapat $\mathrm{dL}=1,4853, \mathrm{dU}=1,7335,4-\mathrm{dL}=2,5147$ dan 4-dU $=2$ 2665. Dapat disimpulkan bahwa $\mathrm{dU}<\mathrm{d}<4$-dU $(1,7335<1,880<2,2665)$ yang berarti bahwa hipotesis nol $\left(\mathrm{H}_{0}\right)$ tidak ditolak atau tidak terjadi autokorelasi.

\section{Regresi Linear Berganda}

Analisis ini bertujuan menghitung seberapa besar terdapat pengaruh antara variabel ROE, EPS, inflasi dan kurs terhadap harga saham.

Tabel 2. Uji Regresi Berganda Coefficients ${ }^{\mathrm{a}}$

\begin{tabular}{|c|c|c|c|c|}
\hline \multirow[t]{2}{*}{ Model } & & \multicolumn{2}{|c|}{ Unstandardized Coefficients } & \multirow{2}{*}{$\begin{array}{c}\begin{array}{c}\text { Standardized } \\
\text { Coefficients }\end{array} \\
\text { Beta } \\
\end{array}$} \\
\hline & & B & Std. Error & \\
\hline \multirow{5}{*}{1} & (Constant) & $-5493,080$ & 14811,800 & \\
\hline & ROE (X1) & 252,404 & 14,150 & ,638 \\
\hline & EPS (X2) & 13,326 & ,916 &, 521 \\
\hline & Inflasi (X3) & $-139,859$ & 315,460 &,- 016 \\
\hline & Kurs (X4) & ,339 & 1,047 &, 012 \\
\hline \multicolumn{5}{|c|}{ Tabel 3. Uji Koefisien Determinasi $\left(\mathbf{R}^{2}\right)$ Model Summary ${ }^{b}$} \\
\hline Model & $\mathrm{R}$ & R Square & $\begin{array}{l}\text { sted } \mathrm{R} \\
\text { lare }\end{array}$ & $\begin{array}{l}\text { Erd. Error of the } \\
\text { Estimate }\end{array}$ \\
\hline 1 & $965^{\mathrm{a}}$ & ,931 & ,927 & 3034,289 \\
\hline
\end{tabular}


Tabel 4. Uji Parsial (Uji t) Coefficients ${ }^{a}$

\begin{tabular}{|c|c|c|c|c|c|}
\hline \multirow[t]{2}{*}{ Model } & \multicolumn{2}{|c|}{$\begin{array}{c}\text { Unstandardized } \\
\text { Coefficients } \\
\end{array}$} & \multirow{2}{*}{$\begin{array}{c}\begin{array}{c}\text { Standardized } \\
\text { Coefficients }\end{array} \\
\text { Beta } \\
\end{array}$} & \multirow[t]{2}{*}{$\mathrm{T}$} & \multirow[t]{2}{*}{ Sig. } \\
\hline & $\mathrm{B}$ & Std. Error & & & \\
\hline (Constant) & $-5493,080$ & 14811,800 & &,- 371 & ,712 \\
\hline ROE (X1) & 252,404 & 14,150 & ,638 & 17,838 &, 000 \\
\hline EPS (X2) & 13,326 & ,916 &, 521 & 14,553 & ,000 \\
\hline Inflasi (X3) & $-139,859$ & 315,460 &,- 016 &,- 443 & ,659 \\
\hline Kurs (X4) & ,339 & 1,047 &, 012 & ,324 & ,747 \\
\hline
\end{tabular}

a. Dependent Variable: Harga Saham (Y)

Tabel 5. Uji Simultan (Uji F) ANOVA

\begin{tabular}{llcc}
\hline Model & & F & Sig. \\
\hline \multirow{2}{*}{1} & Regression & 213,240 &, $000^{\mathrm{b}}$ \\
& Residual & & \\
& Total & & \\
\hline
\end{tabular}

a. Dependent Variable: Harga Saham

b. Predictors: (Constant), Kurs (X4), EPS (X2), Inflasi (X3), ROE (X1)

\section{PEMBAHASAN}

\section{Analisis Regresi Linear Berganda}

Regresi linear berganda penelitian ini dihitung dengan formula berikut:

$$
\mathbf{Y}=\alpha+\beta_{1} \mathbf{X}_{1}+\beta_{2} \mathbf{X}_{2}+\beta_{3} \mathbf{X}_{3}+\beta_{4} \mathbf{X}_{4}+\mathbf{e}
$$

Harga Saham $=-5493,080+252,404$ ROE $+13,326$ EPS $-139,859$ Inflasi + 0,339 Kurs + e

Nilai konstanta sebesar -5493,080 artinya jika ROE, EPS, inflasi dan kurs nilainya nol (0) maka nilai harga saham sebesar -5493,080. Nilai koefisien ROE sebesar 252,404 artinya jika ROE mengalami penurunan sebesar $1 \%$ maka harga saham akan mengalami kenaikan senilai 252,404. Koefisien positif menandakan hubungan positif antara ROE dengan harga saham, semakin tinggi nilai ROE makan akan semakin meninggikan harga saham atau bisa terjadi berarti sebaliknya. Koefisien EPS 13,326 artinya jika EPS turun 1\% maka harga saham akan mengalami kenaikan sebesar 13,326. Koefisien positif menandakan hubungan positif antara EPS dengan harga saham, semakin tinggi nilai EPS, makan mengakibatkan semakin tingginya harga saham demikian pula sebaliknya. Nilai koefisien inflasi sebesar 139,859 artinya jika naik sebesar $1 \%$ dari inflasi, mengakibatkan penurunan harga saham sebesar $-139,859$. Koefisien negatif menandakan hubungan negatif antara inflasi dengan 
harga saham, semakin tinggi laju inflasi maka harga saham akan mengalami kenaikan ataupun sebaliknya. Nilai koefisien kurs sebesar 0,339 artinya jika kurs mengalami penurunan sebesar 1\% maka nilai harga saham akan mengalami kenaikan sebesar 0,339. Koefisien positif mencerminkan hubungan positif antara kurs dengan harga saham, semakin tinggi nilai kurs maka menjadikan semakin tingginya harga saham ataupun sebaliknya.

Adjusted $R$ Square senilai 0,927 yang berarti bahwa variasi variabel independen ROE, EPS, inflasi, dan kurs mampu menjelaskan 92,7\% dari variasi variabel dependen harga saham, sedangkan 7,3\% sisanya merupakan pengaruh dari variabel lain selain variabel penelitian ini. Sedangkan koefisien korelasi (R) 0,965 menunjukkan bahwa kuat hubungan anatara variabel independen terhadap variabel dependen sebesar 96,5\%.

\section{Pengujian Hipotesis}

Hasil uji secara parsial variabel ROE diperoleh nilai $t_{\text {hitung }}$ sebesar 17,838 kemudian nilai $t_{\text {tabel }}$ yaitu sebesar 1,99834 menggunakan rumus $\mathrm{df}=\mathrm{n}-\mathrm{k}-1$ sehingga $\mathrm{df}=68-4-1=63$. Variabel ROE $t_{\text {hitung }}$ sebesar 17,838 dengan demikian $t_{\text {hitung }}>t_{\text {tabel }}(17,838>1,99834)$ yang secara statistik, $\mathrm{H}_{0}$ ditolak dan $\mathrm{H}_{\mathrm{a}}$ diterima atau variabel $\mathrm{ROE}$ mempengaruhi harga saham. Dan untuk nilai tingkat signifikansi yaitu 0,025 atau 2,5\% dengan menggunakan tabel signifikansi hasil mendapat nilai $(0,000<0,025)$. Berdasarkan hasil tersebut, maka secara parsial ROE mempengaruhi harga saham secara positif dan signifikan, sehingga menerima hipotesis pertama (H1) yang menyatakan bahwa ROE berpengaruh terhadap harga secara signifikan dan positif.

Hasil perhitungan uji parsial variabel EPS diperoleh nilai $t_{\text {hitung }}$ sebesar 14,553 kemudian nilai $t_{\text {tabel }}$ yaitu sebesar 1,99834 menggunakan rumus df $=n-k-1$ sehingga $\mathrm{df}=68$ $4-1=63$. Variabel EPS $t_{\text {hitung }}$ sebesar 14,553 dengan demikian $t_{\text {hitung }}>t_{\text {tabel }}(14,553>1,99834)$ yang secara statistik, $\mathrm{H}_{0}$ ditolak dan $\mathrm{H}_{\mathrm{a}}$ diterima. Jadi variabel EPS mempengaruhi harga saham. Tingkat signifikansi yaitu 0,025 atau 2,5\% dengan menggunakan tabel signifikansi hasil mendapat nilai $(0,000<0,025)$. Berdasarkan hasil tersebut, secara parsial EPS memiliki pengaruh yang positif pada harga saham, sehingga hipotesis kedua $(\mathrm{H} 2)$ dapat diterima.

Hasil perhitungan uji secara parsial variabel inflasi diperoleh nilai $t_{\text {hitung }}$ sebesar 0,443 kemudian nilai $\mathrm{t}_{\text {tabel }}$ yaitu sebesar 1,99834 menggunakan rumus $\mathrm{df}=\mathrm{n}-\mathrm{k}-1$ sehingga $\mathrm{df}$ $=68-4-1=63$. Variabel inflasi $t_{\text {hitung }}$ sebesar $-0,443$ dengan demikian $t_{\text {hitung }}<t_{\text {tabel }}(-0,443<$ 1,99834) yang secara statistik, $\mathrm{H}_{0}$ diterima dan $\mathrm{H}_{\mathrm{a}}$ ditolak atau variabel inflasi tidak mempengaruhi harga saham. Tingkat signifikansi yaitu 0,025 atau $2,5 \%$ dengan menggunakan tabel signifikansi hasil mendapat nilai $(0,659>0,025)$. Berdasarkan hasil tersebut menunjukkan inflasi secara parsial tidak mempengaruhi harga saham, sehingga hipotesis ketiga (H3) yang menyatakan bahwa inflasi mempengaruhi harga saham secara negatif signifikan, hipotesis ini ditolak.

Hasil perhitungan uji secara parsial variabel kurs diperoleh nilai $t_{\text {hitung }}$ sebesar 0,324 kemudian nilai $t_{\text {tabel }}$ yaitu sebesar 1,99834 menggunakan rumus $\mathrm{df}=\mathrm{n}-\mathrm{k}-1$ sehingga $\mathrm{df}=68$ $4-1=63$. Variabel inflasi $t_{\text {hitung }}$ sebesar 0,324 dengan demikian $t_{\text {hitung }}<t_{\text {tabel }}(0,324<1,99834)$ 
yang secara statistik, $\mathrm{H}_{0}$ diterima dan $\mathrm{H}_{\mathrm{a}}$ ditolak atau variabel kurs terhadap harga saham, tidak memiliki pengaruh. Dan untuk nilai tingkat signifikansi yaitu 0,025 atau 2,5\% dengan menggunakan tabel signifikansi hasil mendapat nilai $(0,747>0,025)$. Berdasarkan hasil tersebut, maka secara parsial inflasi tak berpengaruh pada harga saham, sehingga hipotesis (H4) bahwa kurs berpengaruh signifikan dan negatif terhadap harga saham, dengan demikian hipotesis ditolak.

Hasil signifikansi secara simultan (Uji F) dapat diketahui bahwa tingkat signifikansi yaitu $0,000<0,05$. Berdasarkan nilai $F_{\text {hitung }}$ dibandingkan dengan nilai $F_{\text {tabel }}$. Hasil $F_{\text {hitung }}$ menunjukkan nilai sebesar 213,240. Nilai $F_{\text {tabel }}$ pada tingkat kesalahan $\alpha=5 \%$ dengan df atau derajat kebebasan $=\mathrm{df}$ pembilang $(\mathrm{k}-1)$ df penyebut $(\mathrm{n}-\mathrm{k})$. Jumlah variabel penelitian $(\mathrm{k})$ berjumlah 4, dan jumlah sampel (n) sebanyak 68. Jadi df pembilang (4-1) = 3 dan df penyebut $(68-4)=64$, sehingga $F_{\text {tabel }}$ pada tingkat kepercayaan 95\% $(\alpha=5 \%)$ adalah 2,75. Jadi $F_{\text {hitung }}>F_{\text {tabel }}(213,240>2,75)$ dan tingkat signifikansi sebesar $0,000<0,05$. Maka dapat ditarik kesimpulan bahwa $\mathrm{H}_{0}$ ditolak dan $\mathrm{H}_{5}$ diterima artinya ROE, EPS, inflasi dan kurs mempengaruhi harga saham secara simultan pada saham perusahaan terdaftar di JII periode 2015-2018.

\section{KESIMPULAN}

Berdasarkan analisis; ROE, EPS, inflasi dan kurs dari harga saham yang tercacat di JII periode 2015-2018, dapat ditarik kesimpulan bahwa: variabel ROE dan EPS secara parsial berpengaruh signifikan positif pada harga saham, sedangkan inflasi dan kurs secara parsial menjadi variabel yang tidak mempengaruhi harga saham JII. Secara simultan ROE, EPS, inflasi, dan kurs berpengaruh terhadap harga saham.

\section{DAFTAR PUSTAKA}

Akbar, T., \& Afiezan, A. (2018). Determinasi Harga Saham Syariah Melalui Analisis Terhadap Faktor Fundamental dan Makro Ekonomi. Jurnal Ilmiah Wahana Akuntansi, Vol.13, Hal.1-12.

Ardana, Y. (2016). Pengaruh Variabel Makroekonomi terhadap Indeks Saham Syariah di Indonesia : Model ECM. Jurnal Bisnis dan Manajemen, Vol. 6 Hal.17-28.

Bank Indonesia. (2019, Oktober). Inflasi. Diambil kembali dari www.bi.go.id: https://www.bi.go.id/id/moneter/inflasi/pengenalan/Contents/Default.aspx

Boediono. (1999). Teori Pertumbuhan Ekonomi. Yogyakarta: BPFE.

Bursa Efek Indonesia. (2019, Oktober 15). Index Saham. Dipetik Oktober 2019, dari www.idx.co.id: https://www.idx.co.id/data-pasar/data-saham/indeks-saham/ 
Darmadji, T., \& Fakhruddin, H. (2012). Pasar Modal Syariah Edisi 3. Jakarta: Salemba Empat.

Desiana, L. (2017). Pengaruh Price Earning Ratio (PER), Earning Per Share (EPS), Devidend Yield Ratio (DYR), Dividend Payout Ratio (DPR), Book Value Per Share (BVS) Dan Price Book Value (PBV) Terhadap Harga Saham Pada Perusahaan Subsektor Makanan Dan Minuman Yang Terdaftar D. Jurnal I-Finance, Vol.3 No.2 Hal.199212.

Fahmi, I. (2014). Manajemen Keuangan Perusahaan Dan Pasar Modal. Jakarta: Mitra Wacana Media.

Harahap, D. (2016). Analisis Faktor-Faktor Yang Mempengaruhi Harga Saham Jakarta Islamic index (JII). Jurnal Analytica Islamica, Vol.5 No.2 Hal.342-367.

Kousar, R., Imran, Z., Khan, Q. M., \& Khurram, H. (2019). Impact of Terrorism on Stock Market: A Case of South Asian Stock Markets. Journal of Accounting and Finance in Emerging Economies, 5(2), 215-242.

Nicolae, B. S., Codruta, M., Violeta, A. M., \& Adriana, P. (2016). DIRECTION OF CAUSALITY BETWEEN FINANCIAL DEVELOPMENT AND ECONOMIC GROWTH. EVIDENCE FOR DEVELOPING COUNTRIES. Studia Universitatis "Vasile Goldis Arad" Economics Series, 26(2), 1-22.

Rachmawati, M., \& Laila, N. (2015). Faktor Makroekonomi Yang Mempengaruhi Pergerakan Harga Saham Pada Indeks Saham Syariah Indonesia (ISSI) di Bursa Efek Indonesia (BEI). JESTT, Vol.2 No.11 Hal.928-942.

Rahmania, E., Mardani, R. M., \& Wahono, B. (2019). Pengaruh Produk Domestik Bruto, Inflasi dan Index Harga Saham Gabungan Terhadap Harga Saham Syariah (Studi Empiris Pada Harga Gabungan Jakarta Islamic Index Tahun 2015-2017). e-Jurnal Risel Manajemen, Hal.45-58.

Riana, I. K., \& Dewi, S. K. (2015). Peran EPS Dalam Memidiasi Pengaruh ROE Terhadap Harga Saham Perusahaan Perbankan di BEI. e-Jurnal Manajemen Unud, Vol.4, No.12 Hal.4245-4273.

Samsul, D. M. (2006). Pasar Modal dan Manajemen Portofolio. Jakarta: Erlangga.

Sari, M. (2016). Pengaruh Nilai Tukar Rupiah, Inflasi dan Suku Bunga Terhadap Harga Saham Pada Perusahaan Yang Terdaftar di ISSI. Artikel Ilmiah.

Sugiyono. (2014). Metode Peneltian Kuantitatif Kualitatif dan $R \& B$. Bandung: Alfabeta.

Syarief, N. H. (2019). Pengaruh Earning Per Share (EPS) dan Dividen Per Share (DPS) Terhadap Harga Saham Pada Perusahaan Otomotif yang Terdaftar di Bursa Efek Indonesia (BEI). e-Jurnal Riset Manajemen, Hal.138-149. 
Tandelilin, E. (2010). Portofolio dan Investasi. Yogyakarta: Kanisius.

Touny, M. A. (2012). Stock Market Development and Economic Growth: Empirical Evidence from Some Arab Countries. Arab Journal of Administration, 32(1), 177197.

Utami, M. R., \& Darmawan, A. (2019). Effect of DER, ROA, ROE, EPS, and MVA on Stock Prices in Sharia Indonesian Stock Index. Journal of Applied Accounting and Taxxation, Vo.4, No.1, Hal.15-22.

Wijayanti, K. D., \& Sulasmiyati, S. (2018). Pengaruh Faktor Internal dan Eksternal Perusahaan Terhadap Harga Saham (Studi pada Perusahaan Sektor Pertambangan yang Terdaftar di Daftar Efek Syariah Periode 2013-2016). Jurnal Administrasi Bisnis, Vol. 55 No.2 Hal.8-14. 